\title{
The process of knowledge transference: a matter concerning of teaching of psychiatric nursing
}

O processo de transferência de conhecimento: uma questão sobre o ensino de enfermagem psiquiátrica

El proceso de transferencia de conocimiento: una cuestión acerca de la enseñanza de la enfermería psiquiátrica

Laís de Mello Santos ${ }^{1}$ Rosane Mara Pontes de Oliveira ${ }^{1}$ Virgínia Faria Damásio Dutra ${ }^{1}$ Isaura Setenta Porto ${ }^{1}$

1. Federal University of Rio de Janeiro. Rio de Janeiro, RJ, Brazil.
Corresponding author:

Virgínia Faria Damásio Dutra.

E-mail: virginia.damasio@gmail.com

Submitted on $12 / 02 / 2016$

Accepted on 02/03/2017.

DOI: 10.1590/2177-9465-EAN-2016-0356

\begin{abstract}
Objectives: To identify the strategies used by teachers to share the contents of Psychiatric Nursing and Mental Health; to describe the stages of knowledge sharing in light of the knowledge transfer process. Method: Qualitative, descriptive-exploratory research of the case study type, carried out with six teachers and 23 students, data production was by semi-structured interview and focus group. For the data analysis, the $\mathrm{SECl}$ knowledge conversion model was used: socialization, externalization, combination and internalization. Results: Teachers made socialization and externalization, but did not make clear the assessment and teaching-learning strategies. The combination was completed, but the internalization was unfinished, despite suggesting an attempt to reach it. Conclusion: The feasibility and applicability of the knowledge transfer process to the teaching of Psychiatric Nursing were confirmed.
\end{abstract}

Keywords: Knowledge; Teaching; Mental Health; Psychiatry Nursing; Learning.

\section{Resumo}

Objetivos: Identificar as estratégias utilizadas pelos docentes para compartilhar os conteúdos de Enfermagem Psiquiátrica e de Saúde Mental; descrever as etapas do compartilhamento de saberes à luz do processo de transferência do conhecimento. Método: Pesquisa qualitativa, descritivo-exploratório do tipo estudo de caso, realizado com seis docentes e 23 discentes, a produção dos dados se deu por entrevista semiestruturada e grupo focal. Para a análise dos dados foi utilizado o modelo SECI de conversão do conhecimento: socialização, externalização, combinação e internalização. Resultados: Os docentes efetuaram a socialização e a externalização, mas não deixam claro a avaliação e as estratégias de ensino-aprendizagem. A combinação foi concretizada, mas a internalização demonstrou-se inacabada, apesar de sugerir uma tentativa de alcança-la. Conclusão: A viabilidade e a aplicabilidade do processo de transferência de conhecimento para o ensino de Enfermagem Psiquiátrica foram comprovadas.

Palavras-chave: Conhecimento; Ensino; Saúde Mental; Enfermagem Psiquiátrica; Aprendizado.

\section{Resumen}

Objetivos: Identificar las estrategias utilizadas por los maestros para compartir el contenido de Enfermería Psiquiátrica y Salud Mental; describir los pasos de la puesta en común de los conocimientos a la luz del proceso de transferencia de conocimientos. Método: Cualitativa, descriptiva y exploratorio, estudio de caso, realizado con seis profesores y 23 estudiantes, la producción de datos era por medio de entrevistas semi-estructuradas y grupos focales. Para el análisis de datos se utilizó el modelo SECI de conversión del conocimiento: la socialización, exteriorización, combinación e interiorización. Resultados: Los maestros efectúan la socialización y la externalización, pero no hacen las estrategias de evaluación y de enseñanza-aprendizaje claros. La combinación se terminó, pero la internalización demostró ser sin terminar, a pesar de sugerir un intento de llegar a él. Conclusión: Viabilidad y la aplicabilidad del proceso de transferencia de conocimientos a la enseñanza de la enfermería psiquiátrica han sido probados.

Palabras clave: Conocimiento; Educación; La Salud Mental; Enfermería Psiquiátrica; Aprender. 


\section{INTRODUCTION}

Nursing has, in its essence, the care as an instrument of work and study. The construction of the nursing knowledge body, as a science, guarantees the professional identity, autonomy, authority and responsibility of the profession. Nursing seeks to instrument care through the approximation of theoretical and practical knowledge, as a discipline with predominance in the logic of scientific, empirical and analytical rationality, while respecting the subjectivity of each user and the human creativity of each professional. ${ }^{1}$

Knowledge is an inherent capacity to the human being, of tacit character, governed by action and based on rules, being individual and changeable. It is endowed with an individual content that is expressed through the skills, experiences, judgments of value and social network. To be perceived, knowledge has to be provided with meaning, because without it the process of knowledge transfer becomes inert and static, without real relevance in the generation of new knowledge, concepts and definitions, in search of its validation as truth. ${ }^{2}$

Knowledge can be derived in two ways: ${ }^{3}$ the explicit, which is characterized as a fast and simple mean for internalization or storing; and the tacit, that is a specific form of knowledge which is held in the mind of the individual, that is, it is difficult to access. However, it can still be shared, forming a collective knowledge that sometimes becomes explicit. This includes the SECI model of knowledge conversion, comprised by the steps of Socialization, Externalization, Combination and Internalization (SECI), which enable the process of knowledge transfer between individuals.

There are at least four ways of knowledge conversion: Socialization, which transforms tacit knowledge into tactical knowledge; Externalization, which transforms tacit knowledge into explicit knowledge; Combination, that transforms explicit knowledge into explicit knowledge and Internalization, which transforms explicit knowledge into tacit knowledge. Socialization comes from the sharing of experiences and technical skills in the daily experience of work. Externalization articulates and organizes explicit tacit knowledge through dialogue and group reflection of a theme, and is constructed through written language, providing a symbolic mark to the creation of knowledge. The combination is the reconfiguration and categorization of explicit knowledge, giving it the opportunity to generate new knowledge through information networks. Internalization is the process where the incorporation of explicit knowledge into tacit occurs, promoting change, enhancement and development of individual and collective practices. ${ }^{4}$

Over many years, Psychiatric Nursing has guided its teaching technologies in the discipline through the containment, medicalization and exclusion of the subject. Nowadays, mental health technologies are added to the creative and reciprocal knowledge used in teaching to approximate theory to practice and reduce the divergences between what is taught and what is learned in the academy, in order to assist the improvement of the process of taking care of the other. ${ }^{5}$

Changes in the scope of the quality of care provided to people with mental disorders resulting from the Psychiatric Reform process led to the creation of several substitute devices to asylums with the purpose of reformulating the practice of mental healthcare by providing assistance to individual autonomy, freedom and means of social inclusion. Faced with this context, there was a need for adequate knowledge, practice and Mental health assistance. However, the attempt to break with the hospital-centered model is complex, requiring the Psychiatric Nursing to break the medicament paradigm, contain and monitor, giving way to the construction of new rehabilitative care strategies and promote effective care, which demand the generation of new knowledge. , $^{6}$

It requires new forms of teaching, building possibilities for mental healthcare, such as: interpersonal relationship, therapeutic project design, therapeutic residency, social inclusion, psychosocial rehabilitation, interprofessional, territorial and intersectoral attention. Thus, the process of training nurses, associated to the importance of integration and reflection of knowledge and practices, aims to train a professional with skills to act, according to the collective and social context, sustained in the new model of assistance, integral and humanized. ${ }^{5-8}$

With this, the study aimed to identify the strategies used by the teachers to share the contents of Psychiatric Nursing and Mental Health; to describe the steps of knowledge sharing in light of the knowledge transfer process.

\section{METHOD}

The study has a qualitative approach of the descriptiveexploratory type, having as a research design the case study, since it aims to identify the process of knowledge transfer in Mental Health provided to undergraduate students. The research scenario was a public nursing school. The participants were students enrolled and attending the $7^{\text {th }}$ period and teachers who make up the core of Psychiatric/Mental Health Nursing, totaling six professors, of which three have permanent link with the institution and the other three are in the position of substitute teachers who have a contract of one year extendable by another one year with the institution.

Data collection took place in two stages: first, observation of classes and interviews with teachers; and second, a focus group with the students. For the observation, a systematic behavioral technique and notes, a field diary, through the non-participant observation of classes taught by teachers, with focus on knowledge transfer mechanisms used. For the interview was used a verbal-linguistic technique, based on an open-ended interview conducted according to a semi-structured script, composed of questions that permeate the methodological approach used and the professional trajectory of the teacher. 
In the second step, data collection with the students, occurred through a focus group from a semi-structured script composed of questions that come with the understanding and the views of students in relation to lectures given by the teachers. The script of the focal group included the expectations, evaluation and learning of students.

The data collection period was from October 2014 to April 2015 and the distribution of the number of interviews conducted with each teacher was performed according to the number of classes each one ministered. The data obtained from the first stage totaled 38 hours of non-participant observation and 12 interviews. The focus group had a duration of 60 minutes, with the participation of 23 subjects randomly. The data were analyzed based on the Content Thematic Analysis, in order to obtain indicators to generate inferences about the messages. ${ }^{9}$ The research obeyed the ethical and legal precepts of Res. 466/12, obtained approval in the EEAN/HESFA zip code, Number: 824,821 on $10 / 27 / 2014$. The participants signed the Free and Informed Consent Term.

\section{RESULTS}

Based on the analysis of the data, emerged four categories, namely: Socialization as a sensation or as a teaching belief; Strategies as a way of externalizing knowledge; Aggregating knowledge: the use of the combination to apprehend Mental Health; and the Internalization of knowledge orienting future nurses.

The teachers' statements (Table 1) expose the instruments used so that the students could not only absorb the content taught throughout the discipline, but also put it into practice in their care actions developed in all the clinics that involve the process of physical illness and/or mental health, where Nursing performs its task of caring.

The teacher, by ensuring to the student the instruments that allow the understanding of psychic illness process and its determining factors, are contributing greatly to the student being able to understand the subject in the face of its complexity and subjectivity, since it is only possible to perform care when someone can visualize the dimension and the degree of physical, motor and social impairment imposed to the subject by the mental disorder.

From the speeches of the students (Table 2) it is possible to verify the change in the thinking of the students regarding the field of Mental Health, where the fear of the unknown and the stigma allow the discovery of what really happens with the individual in psychic suffering. This situation was only possible by stimulating the association of the theoretical and practical fields, where students try to associate the examples and contents provided in the classroom with the know-hows they have experienced in practice.
During the learning process, the student envisages achieving at the end of the discipline the greatest amount of knowledge to be able to act facing customers in various fields and areas of nursing. However, it is worth mentioning that, quantity not always has quality, so it is important that students understand that for that knowledge to be able to generate positive results in future employment, it must be worked, stimulated, enhanced, developed and apprehended.

In this process, the student needs to perform the function of a "sculptor", which first selects the raw material of his work, then separates the material to be used in its construction, then molds and develops the premise of the work with care and effort, and after the long day at work, his final work for the sculptor's always unfinished because everything is better with a few touch-ups and dedication. Thus, it is the student who has a knowledge to be acquired, he chooses the tools and strategies he will use to apprehend it, after much study and development, he will be able to develop it in practice, however, it is always possible to learn more and more.

\section{DISCUSSION}

The category called socialization as sensation or teaching belief refers to the feeling experienced by teachers in the process of socialization of knowledge. Along the production of data, we are faced with the fragility in most answers given by teachers, who report having the desire and the pretension to reach the objectives proposed in the classroom with the intention of continuing the socialization stage. However, such expressions characterize the implementation of the objectives of the lesson and this category only in the ambit of thinking and believing.

It also concerns the first stage of the knowledge transfer process determined by the sharing of experiences and technical skills in the daily work experience. It is characterized by the knowledge propagated by the teacher in its breadth and diversity, not with the intention of transferring the knowledge to the students as mere repositories of information, but rather providing space for the development of care practices that corroborate with personal, intellectual and psychosocial enrichment of the student, so that they can become critical subjects in relation to the theory and practice in Psychiatric Nursing and Mental Health.

In order that the student can comprehend and, moreover, understand the meaning of the contents taught, teachers use as main tool the correlations and integrations between theory and practical experience, so that the student can visualize, being in person in practical field or only from the experiential account of teaching that knowledge inserted and contextualized in a real situation of everyday life by providing subsidies to go into the field of the unknown. 
Table 1. Consolidation of teachers' speeches with the emerging categories of the study.

\begin{tabular}{|c|c|c|c|}
\hline $\begin{array}{l}\text { Socialization as feeling or } \\
\text { teaching belief }\end{array}$ & $\begin{array}{l}\text { Strategies as a way to } \\
\text { externalize knowledge }\end{array}$ & $\begin{array}{l}\text { Aggregating knowledge: the } \\
\text { use of combination to learn } \\
\text { Mental health }\end{array}$ & $\begin{array}{l}\text { Internalization of knowledge } \\
\text { coaches future nurses }\end{array}$ \\
\hline $\begin{array}{l}\text { [...] Another important issue } \\
\text { is precisely the visualization } \\
\text { of the concrete reality, when } \\
\text { you locate with examples, } \\
\text { events, with experiences } \\
\text { lived throughout the process. } \\
\text { (Doc. } 310 / 17 / 14 \text { ) } \\
\text { [...] My great strategy } \\
\text { is to use examples from } \\
\text { my experience and } \\
\text { practical testimonies. } \\
\text { (Doc. } 410 / 24 / 14 \text { ) } \\
\text { [...] I think the more complex } \\
\text { contents need to be shared } \\
\text { through practical experience. } \\
\text { (Doc. } 603 / 27 / 15) \text {. }\end{array}$ & $\begin{array}{l}\text { [...] I Work with audiovisual } \\
\text { methods. (Doc. } 2 \text { 10/13/14) } \\
\text { [...] I work a lot with } \\
\text { dynamics. Interactive } \\
\text { activities in the classroom. } \\
\text { (Doc. } 108 / 22 / 14 \text { ) } \\
\text { [...] Lectures and dialogues, } \\
\text { trying to problematize } \\
\text { so that the teaching has } \\
\text { meaning. (Doc. } 603 / 27 / 15 \text { ) } \\
\text { [...] We bring accessory } \\
\text { literature of books or articles } \\
\text { that bring the problem } \\
\text { in a more current way. } \\
\text { (Doc. } 108 / 22 / 14 \text { ) } \\
\text { [...] I work a lot with } \\
\text { audiovisual material. } \\
\text { (Doc.1 08/22/14) }\end{array}$ & $\begin{array}{l}\text { [...] One way of thinking } \\
\text { psychiatry beyond itself, is } \\
\text { to think Psychiatry from the } \\
\text { relationship between Mental } \\
\text { Health and mental illness. } \\
\text { (Doc. } 3 \text { 10/17/14) } \\
\text { [...] Dialogue, debate and } \\
\text { reflection without losing } \\
\text { the categorization or the } \\
\text { rationality of the process } \\
\text { of knowledge construction. } \\
\text { (Doc. } 310 / 17 / 14 \text { ) } \\
\text { [...] That one can take } \\
\text { that knowledge to his/her } \\
\text { attendance in every clinic. } \\
\text { (Doc. } 108 / 22 / 14 \text { ) }\end{array}$ & $\begin{array}{l}\text { [...] Providing them a more } \\
\text { assertive and directive } \\
\text { (safe) posture in any } \\
\text { area regardless of being } \\
\text { of mental health or not. } \\
\text { (Doc. } 108 / 22 / 14 \text { ) } \\
\text { [...] He better understand } \\
\text { how this individual acts, } \\
\text { it already draws him lay } \\
\text { thought that society has so } \\
\text { he pays much better care. } \\
\text { (Doc. } 210 / 31 / 14 \text { ) } \\
\text { [...] Strengthen autonomy } \\
\text { and even give security in his } \\
\text { actions as a professional. } \\
\text { (Doc. } 210 / 13 / 14 \text { ) }\end{array}$ \\
\hline
\end{tabular}

Table 2. Consolidation of students' speeches with the emerging categories of the study.

\begin{tabular}{|c|c|c|c|}
\hline $\begin{array}{l}\text { Socialization as feeling or } \\
\text { teaching belief }\end{array}$ & $\begin{array}{l}\text { Strategies as a way to } \\
\text { externalize knowledge }\end{array}$ & $\begin{array}{l}\text { Aggregating knowledge: the } \\
\text { use of combination to learn } \\
\text { Mental health }\end{array}$ & $\begin{array}{l}\text { Internalization of knowledge } \\
\text { coaches future nurses }\end{array}$ \\
\hline $\begin{array}{l}\text { [...] The stigma that we bring } \\
\text { of the patient with mental } \\
\text { disorder is very strong, of the } \\
\text { aggressiveness, the violence, } \\
\text { of not knowing how to act } \\
\text { or dealing does not generate } \\
\text { interest in people, but we can } \\
\text { change in our head and our } \\
\text { reflection on the psychiatric } \\
\text { patient. (GF12/11/14) } \\
\text { [...] My expectations were } \\
\text { positive, I thought it was } \\
\text { going to be difficult, but I } \\
\text { never imagined meeting } \\
\text { people as similar to me as I } \\
\text { did, so this was positive for } \\
\text { me. (GF12/11/14). }\end{array}$ & $\begin{array}{l}\text { [...] I have turned to articles } \\
\text { and group discussions to } \\
\text { absorb what everyone has } \\
\text { understood and what it } \\
\text { would be possible to apply in } \\
\text { practice. (GF12/11/14) } \\
\text { [...] I researched at home } \\
\text { on articles and books and } \\
\text { was very pleasurable to me. } \\
\text { It helped me deal with and } \\
\text { recognize, for my perception } \\
\text { of these people has } \\
\text { increased over the period. } \\
\text { (GF12/11/14) } \\
\text { [...] We can put it into } \\
\text { practice and think more and } \\
\text { reaffirm the content within } \\
\text { ourselves. GF12/11/14) }\end{array}$ & $\begin{array}{l}\text { [...] In practice the greatest } \\
\text { contribution is in the } \\
\text { interpersonal relationship } \\
\text { with the patient, to break the } \\
\text { stigmas and try to establish } \\
\text { the bonding relationship. } \\
\text { (GF12/11/14) } \\
\text { [...] Deconstruction of } \\
\text { preconceptions and } \\
\text { paradigms that we had } \\
\text { before towards the person } \\
\text { with mental disorders. } \\
\text { (GF12/11/14) } \\
\text { [...] I think it's important that } \\
\text { the nurse uses itself as a } \\
\text { therapeutic tool for the other. } \\
\text { (GF12/11/14) }\end{array}$ & $\begin{array}{l}\text { [...] It is a very theoretical } \\
\text { content and difficult to } \\
\text { understand, to assimilate } \\
\text { and translate to the practical } \\
\text { scenario. (GF12/11/14) } \\
\text { [...] The contents were very } \\
\text { extensive and taught in a not } \\
\text { very didactic way, making } \\
\text { the content uninteresting and } \\
\text { difficult to understand and to } \\
\text { be interesting. (GF12/11/14) } \\
\text { [...] The levels of classes } \\
\text { are totally different, there } \\
\text { are very good classes and } \\
\text { also classes that you do not } \\
\text { understand. (GF12/11/14) }\end{array}$ \\
\hline
\end{tabular}


The teacher has a set of experiences and knowledge intertwined in a metric of continuous learning. In order to make the knowledge more concrete for the student, the teacher expresses through examples and correlations all his experience lived along the professional practice. It is also necessary for this knowledge to be more easily absorbed and understood by the student that the teacher acts directly in the practice with him.

The dimension of practical experience is important for student learning, as it generates the valorization of the potential of users, territory and family. It is possible to observe that the experiences lived by the students contribute to the understanding of the importance of the therapeutic bond, the affection as a resource and the potential of the interpersonal relation, as a facilitator of the teaching-learning process. ${ }^{10}$

In the context of knowledge mobilization, for the attention in mental health to be based on the integrality of the care it is necessary to equip the professional with a know-how and a know-learn in nursing based on their theoretical and practical skills, on how to act and react, in decision-making, initiative, skills acquired and improved over the course of the professional practice. ${ }^{11}$

From the data collected, there was the concern of teachers in providing subsidies to students so that they could understand the care in Psychiatric Nursing and Mental Health in all its dimensions, as for in relation to the political context, treatment, diagnosis, the process of illness, to assistance, the deconstruction of objectivity, theories based on the care and interaction between the subject receiver and the subject that promotes care.

The category called strategies as a way to externalize knowledge comprises the second stage of the knowledge transfer process called externalization, which is the sharing of knowledge through dialogue, reflection and written language, in which it is possible from a dynamic articulation to provide a symbolic nature to knowledge. This category brings us to the understanding that many resources are needed to teach in order to overcome the barriers of understanding and apprehension of knowledge beyond the boundaries of the classroom. The teacher requires strategies, resources and, above all, cognitive and personal skills to reach the essence of the student and make him/her understand what really the care is for Psychiatric/ Mental Health Nursing making a difference in the lives of those individuals.

In this category, the resources that the teachers use and believe to be facilitators of the process of understanding the content taught in the classroom by the student are presented. It is about how the transformation of the raw and dense knowledge (tacit) into something more tangible and easy (explicit) for the student's understanding occurs through teaching-learning strategies adopted by teachers.
A study ${ }^{5}$ identified teaching-learning strategies that have predominated in 20 nursing undergraduate courses in the area of Mental Health. The authors report the predominance of lecture and dialogue classes and point out: seminars; dynamics and work groups; reading and discussion of texts; use of films to develop a theme of mental health; search in databases in order to search for articles on mental health; construction of problem situations in the community; debates in plenary and groups; creation of artistic and educational material; theoretical and practical activities in health services and metal health/psychosocial care; workshops individual and collective production of texts; discussion of clinical cases and directed studies.

One reflection that is important in relation to what was presented by the participant teachers of the study regarding the teaching-learning strategies is to highlight the fact that many of them use the words 'materials' and 'methods' to describe the strategies used in the classroom. It is noteworthy to point out that there is an important conceptual difference between what means resource and material and, mainly, strategy.

The strategies are seen as a work script, where the professional reflects on the didactic sequence of the activities to be developed in the classroom according to the objectives proposed to be achieved during the lesson. Another important highlight is the differentiation between resources and materials. The materials include the class of tangible tools. The resources include the didactic tools that help the teacher to promote the learning more effectively, so they are seen as strategies of reading, group work, use of audios or videos, games (including virtual ones), simulations, through a certain dynamics, newspapers, books, magazines, CDs, CD-ROMs, websites, etc. ${ }^{12}$

A study ${ }^{13}$ about teaching practice used as base Didactic Content Knowledge, which refers to the teacher as transformer of content in something teachable and comprehensible to the student through the selection of materials, analogies, examples, metaphors and explanations. For this, the teacher needs to understand that it is not a didactic technique, nor a reflective practice, nor a scientific knowledge, but a metric composed of all these elements. ${ }^{13}$

The implementation of the second stage of the teachinglearning process is characterized from the speech of the students, but this effectiveness becomes impaired from the moment that the teacher cannot express effectively in the choices and nomenclatures provided to the facilitating strategies and resources of the teaching-learning process.

The category named as aggregating knowledge: the use of the combination to apprehend Mental Health emerged from the third stage of the process of knowledge transfer - combination, applied to the teaching-learning process in Psychiatric Nursing and Mental Health, being this stage defined as a reconfiguration 
and categorization of knowledge, in order to generate the opportunity to expand knowledge through information networks. The information networks in this context are understood as the attempt to transpose the limits of the classroom, in order to broaden the field of understanding of the students. It is noteworthy that it is possible to affirm that this stage was concluded, since the subjects express the need to group the knowledge to apprehend Mental Health and to use it in all their professional life.

In the past, teacher was the only way to acquire knowledge, but this scenario changed with the advent of information technology. Today, through the internet, the student can access various information that can contribute to their learning. In this new educational scenario, the teacher also has the role of guiding the student in the search and selection of information pertinent to their training process so that they can obtain and deepen the knowledge. These resources come with the intention of adding more value to the learning process and transforming the way of teaching and learning the knowledge. ${ }^{14}$

The teacher, faced with this revolutionary era of real-time digital communication, needs to become a mediator of the information acquired by the student through such digital sources, for which the teacher needs to incorporate such technologies into its teaching methodology rather than the convenience of the mere discursive classes. Which makes the teacher a guiding and transforming learning process beyond the four walls of the classroom, making the student think, stimulates their thinking, and solves problem situations, analyzes data, and builds solutions. "Teachers of the future should be seen as cognitive architects of knowledge. Someone who plans every day his way of teaching, which emphasizes research and mediation". 15:100

In the exercise of learning, the student is seen as a main actor, because without him knowledge would be doomed to the end, because there would be no conditions for the propulsive spring of knowledge to penetrate new spaces and target audiences, because it is this global dimension that the student gives the knowledge that makes it something infinite and unfinished, always requiring an individual to develop and share with the world to make a difference in people's lives. For this, knowledge must be shared, discussed and debated with as many individuals as possible so that by the end of the day it can be understood as inherent knowledge to all who feed on it.

The category called internalization of knowledge coaches future nurses encompasses the last step in the process of knowledge transfer: the internalization. It is characterized as the incorporation of knowledge from the change, enhancement and enrichment of individual and collective practices. Such category is seen as the final step where the student can learn and put into practice all the knowledge acquired and take it for the rest of his life. There is no way to say that this step was reached, because the students are still in the process of training, but you can see the attempt by the teachers in taking them to reflect and to build certain professional skills along the discipline and effort in search of learning by the students that returns to the beginning of the cycle for the step known - socialization, as a new attempt to reach the internalization of knowledge.

The autonomy of the subject arises from a continuous critical reflection on the professional practice, narrowing the distances between what to say and what to do, that is, between theory and practice, making the professional safe from actions and making them have a good professional performance. Thus, the student should not become mere recipients of the process of transfer of knowledge made by the teacher, but rather, an analyzer of these flavors that served as a basis for the construction of skills, perceiving themselves before the professional field ethically responsible for their actions. ${ }^{16}$

It is observed, in the teachers' speeches, the transversality that the knowledge of Mental Health and Psychiatric Nursing have in front of the other areas of health, in this way the teachers need to train students who can take this knowledge beyond the psychiatric clinic, applying it in any relationship of care. The emphasis given on the professional posture and autonomy exercised by the nurse is essential for the student to be positioned in the face of the subject's problem, be it physical, mental or social.

The quality of psychiatric nursing care comes from theoretical and practical knowledge, skills such as posture and ethics, beliefs and values imputed to professional practice, to the subject and his family. The knowledge, skills and experiences developed by nursing need continuous improvement and, for this, the professional needs to constantly reflect and evaluate their professional practice. ${ }^{17}$ They are contributing factors in the construction of knowledge: experience, interpersonal relationship, basic knowledge, balance of theory with practice, exchanges of knowledge and applicability of knowledge in practice. ${ }^{18,19}$

Knowledge is taken as the raw material of progress of science of the today world, but the World Health Organization reports that there is a gap between the advances of science and the practical application and diffusion of knowledge. Thus, it becomes impracticable to affirm that the process of knowledge transfer in nursing occurs in a safe and effective way, however, to promote knowledge without transferring it generates a cycle of professional frustrations. ${ }^{20}$

It is observed the concern to provide subsidies to the student, so that it has a leadership position and is able to develop effective, fast and precise decision-making in the moments when it is necessary during its evaluation of the problem situations that arise along of daily work.

It was highlighted as possible causes of the impossibility and fragility of the reach of the internalization stage: the predisposition and choice of students for other areas of interest; the particularity that each teacher has for teaching; the immaturity of students who enter universities at an earlier age; low professional maturity of teachers; the lack of full knowledge of the curriculum by teachers; the Psychiatric Nursing and Mental Health, to be unique 
and in the $7^{\text {th }}$ period, the short time of contact of the student with the subject and the rotation of the substitute teachers.

\section{CONCLUSION}

The data have provided subsidies to conclude that teachers perform the first three stages of the process of knowledge transfer, called:Socialization, Externalization and Combination; however, in the first two steps, it is possible to observe failures in the process as regards to not making the lesson plan and the lack of use of evaluation tools of learning of the student in each class, not allowing, thus, the confirmation of the achievement of the objectives of the classes and the other weakness found was in relation to the strategies used by the teachers to facilitate the understanding and apprehension of knowledge, because they cannot define exactly the difference between the use of resources, strategies or materials during their application in classes.

The stage of Internalization, in which the student needs to be able to effectively put into practice the valorization, change and enrichment of knowledge, was not completed during the process of knowledge transfer, since it was a moment in which students should be more secure in the process of apprehension and development of the knowledge to act with the clientele, however, it was still possible to observe them apprehensive and insecure to deal with the clientele. Therefore, it cannot be said that the students reached the goals proposed by the teachers at the end of the course. However, one can observe the resumption of the cycle of transfer of knowledge by students as an attempt to reach the Internalization.

It is concluded that it is a time when students are in the process of training, development of learning and construction of the knowledge framework that will lead to professional life. It is possible to identify that it is not enough for the teacher to have the desire to teach the student to apprehend Mental Health, it must have theoretical, didactic and personal tools to develop this process. It can be concluded, however, that the research has achieved its objectives, since the possibility and applicability of the process of knowledge transfer to the teaching of Psychiatric Nursing and Mental Health were proven by the construction and appropriateness of the steps/categories with the data of the study.

\section{REFERENCES}

1. Oguiso T, Freitas GF. Care - The Essence of the Nursing Professional Identity. Rev Esc Enferm USP [Internet]. 2016 Apr; [cited 2017 Jan 19]; 50(2):188-193. Available from: http://www.scielo.br/scielo. php?script=sci arttext\&pid=S0080-62342016000200188\&Ing=en. http://dx.doi.org/10.1590/S0080-623420160000200001

2. Pacheco ASV, Rissi M, Ferreira JMC, Nakayama MK. Dimensionamento do Sistema de Transferência de conhecimento científico e tecnológico do Socius/ISEG, da Universidade Técnica de Lisboa. GUAL [Internet]. 2011 set/dec; [cited 2017 Jan 19]; 4(3): 103-125. Available from: https://periodicos.ufsc.br/index.php/gual/article/ view/1983-4535.2011v4n3p103/21982. http://dx.doi.org/10.5007/1983$4535.2011 \mathrm{v} 4 \mathrm{n} 3 \mathrm{p} 103$
3. Nonaka I, Takeuchi H. Criação de Conhecimento na empresa: como as empresas japonesas geram a dinâmica da inovação. $4^{a}$ ed. Rio de Janeiro: Campus; 1997. 358p.

4. Cunha AJM, Ferreira MAT.Transferência de conhecimento em empresas multinacionais estudo de caso na indústria de papel. Perspec Ciênc Inform [Internet]. $2011 \mathrm{abr}$; [cited 2017 Jan 19]; 16(4):95-118. Available from: http://www.scielo.br/pdf/pci/v16n4/v16n4a08. http://dx.doi. org/10.1590/S1413-99362011000400008

5. Rodrigues J, Pinho LB, Spricigo JS, Santos SMA. Uso da criatividade e da tecnologia no ensino da crise em enfermagem psiquiátrica e saúde mental. SMAD, Rev Eletrônica Saúde Mental Álcool Drog [Internet]. 2010 Jan; [cited 2017 Jan 19]; 6(1):1-19. Available from: http://www.revistas. usp.br/smad/article/view/38708/41559. http://dx.doi.org/10.11606/ issn. 1806-6976.v6i1p1-19

6. Pereira EC, Costa-Rosa A. Problematizando a Reforma Psiquiátrica na atualidade: a saúde mental como campo da práxis. Saude Soc [Internet]. 2012 dez; [cited 2017 Jan 19]; 21(4):1035-43. Available from: http://www.scielo.br/scielo.php?script=sci_arttext\&pid=S0104 $12902012000400020 \&$ Ing=en. http://dx.doi.org/10.1590/S010412902012000400020

7. Guimarães AN, Borba LO, Larocca LM, Maftum MA. Mental health treatment according to the asylum model (1960 to 2000): nursing professionals' statements. Texto Contexto - Enferm [Internet]. 2013 Jun [cited 2017 Jan 19];22(2):361-9. Available from: http://www.scielo.br/scielo.php?script=sci_arttext\&pid=S0104-07072013000200012\&lng=en . http://dx.doi.org/10.1590/S0104-07072013000200012

8. Magnago C, Tavares CMM. O ensino de enfermagem psiquiátrica nas Universidades Públicas do Estado do Rio de Janeiro. Rev Eletr Enf [Internet]. 2012 jan/mar; [cited 2017 Jan 19]; 14(1):50-8. Available from: https://www.fen.ufg.br/fen_revista/v14/n1/pdf/v14n1a06.pdf. http:// dx.doi.org/10.5216/ree.v14i1.10626

9. Bardin L. Análise de conteúdo. São Paulo: Edições 70; 2011. 229p.

10. Cortes JM, Kantorski LP, Barros S, Antonacci MH, Chiavagatti FG, Willich JQ. Saberes e fazeres que integram o ensino de enfermagem psiquiátrica na perspectiva de enfermeiros docentes. Rev Portug Enferm Saúde Mental [Internet]. 2014 dez; [cited 2017 Jan 19]; (12):34-42. Available from: http://www.scielo.mec.pt/pdf/rpesm/n12/n12a05.pdf

11. Lucchese R, Castro P, Ba S, Rosalem V, Silva A, Andrade M, et al. Professional knowledge in primary health care of the person/family in mental distress: Le Boterf perspective. Rev Esc Enferm USP [Internet]. 2014 Dec; [cited 2017 Jan 20]; 48(spe2):123-31. Available from: http://www.scielo.br/scielo.php?script=sci_arttext\&pid=S008062342014000800123\&lng=en. http://dx.doi.org/10.1590/S0080623420140000800019

12. Mazzioni S. As estratégias utilizadas no processo de ensinoaprendizagem: concepções de alunos e professores de ciências contábeis. Rev Eletr Administr Turismo-ReaT [Internet]. 2013 Jan/Jun [cited 2017 Jan 20];2(1):93-109. Available from: https://periodicos.ufpel. edu.br/ojs2/index.php/AT/article/view/1426/2338

13. Backes VMS, Moyá JLM, Prado ML. The construction process of pedagogical knowledge among nursing professors. Rev Latino-Am Enfermagem [Internet]. 2011 Apr; [cited 2017 Jan 20]; 19(2):4218. Available from: http://www.scielo.br/scielo.php?script=sci arttext\&pid=S0104-11692011000200026\&lng=en. http://dx.doi. org/10.1590/S0104-11692011000200026

14. Barros S, Claro HG. The teaching-learning process in mental health: the student's perspective about psychosocial rehabilitation and citizenship. Rev Esc Enferm USP [Internet]. 2011 Dec; [cited 2016 Jul 30]; 45(3):698-707. Available from: http://www.scielo.br/scielo. php?script=sci_arttext\&pid=S0080-62342011000300022\&Ing=en\&nr m=iso. http://dx.doi.org/10.1590/S0080-62342011000300022

15. Viera MM. Educação e Novas Tecnologias: o papel do professor nesse cenário de inovações. Rev Esp Acad [internet]. 2011; [cited $2016 \mathrm{Jul}$ 30]; 11(129):95-102. Available from: http://ojs.uem.br/ojs/index.php/ EspacoAcademico/article/viewFile/14359/8641

16. Freire P. Pedagogia da autonomia. Saberes necessários a prática educativa. 15a ed. São Paulo: Paz e Terra; 2000. 144p. 
17. Benito GAV, Tristão KM, Paula ACSF, Santos MA, Ataide LJ, Lima RCD. Desenvolvimento de competências gerais durante o estágio supervisionado. Rev Bras Enferm. [Internet]. 2012 fev; [cited 2017 Jan 20]; 65(1):172-8. Available from: http://www.scielo.br/scielo. php?script=sci_arttext\&pid=S0034-71672012000100025\&lng=en. http://dx.doi.org/10.1590/S0034-71672012000100025

18. Fuillerat NP. Enfermería Basada en Evidencia y Transferencia de Conocimiento. Index Enferm [Internet]. 2015 Jun; [cited 2016 Nov 20]; 24(1-2):5-6. Available from: http://www.scielo.cl/scielo.php?script=sci_ar ttext\&pid=S0717-95532015000200012. http://dx.doi.org/10.4321/ S1132-12962015000100001
19. Lapeña-Moñux YR, Cibanal-Juan L, Orts-Cortés MI, Maciá-Soler ML, Palacios-Ceña D. Nurses' experiences working with nursing students in a hospital: a phenomenological enquiry. Rev Latino-Am Enfermagem [Internet]. 2016 Jul; [cited 2016 Aug 02]; 24:e2788. Available from: http://www.scielo.br/scielo.php?script=sci_arttext\&pid=S0104$11692016000100352 \&$ Ing=en. http://dx.doi.org/10.1590/15188345.1242.2788

20. Lagos-Garrido ME, Paravic-Klijn T. Generación, difusión y transferencia del conocimiento de enfermería a la práctica del cuidado. Cienc Enferm [Internet]. 2015 ago; [cited 2016 Nov 20]; 21(2):127-34. Available from: http://www.scielo.cl/scielo.php?script=sci_arttext\&pid=S071795532015000200012\&lng=es. http://dx.doi.org/10.4067/S071795532015000200012 